\title{
ANALISIS MATEMATIS DAN EKONOMIS PENGGUNAAN METANOL DAN ETANOL PADA KOMPOR "HD"
}

\author{
DWI PRIYO UTOMO \\ Program Studi Pendidikan Matematika, FKIP Universitas Muhammadiyah Malang \\ E-mail: dwipuumm@yahoo.com
}

\begin{abstract}
ABSTRAK
Kebutuhan energi yang tinggi mengakibatkan harga bahan bakar semakin meningkat. Hal ini berdampak pada sektor dunia usaha, karena biaya produksi semakin meningkat tanpa diimbangi peningkatan daya beli pasar. Salah satu upaya yang bisa dilakukan adalah penggunaan bahan bakar alternatif yang ekonomis, seperti:bioetanol, alkohol, metanol, dan etanol. Unytuk menguji efisiensi bahan bakar itu dibutuhkan kompor yang sesuai. Pada penelitian ini digunakan alat pemanas yang bernama kompor "HD". Metode yang digunakan untuk mengetahui tingkat efisiensi penggunaan bahan bakar metanol dan etanol adalah metode air mendidih. Pengukuran dilakukan terhadap parameter: volume air dalam panci, suhu air sebelum dipanaskan, berat penggunan bahan bakar, berat jenis bahan bakar, perbedaan temperature, total energi diserap, jumlah energi diserap, energi minimum yang diperlukan, dan jumlah air yang dididihkan. Berdasarkan hasil analisis matematis, disimpulkan bahwa penggunaan bahan bakar etanol memiliki kecepatan pendidihan lebih tinggi dibandingkan metanol. Penggunaan bahan bakar metanol kadar 85\% pada kompor HD lebih ekonomis karena terjadi penghematan Rp 544.984,00 untuk peternakan ayam potong per 1000 ekor dalam satu periode usaha 40 hari.
\end{abstract}

Kata kunci: kompor HD, metanol, etanol, and analisis matematis-ekonomis

\section{ABSTRACT}

High energy requirements result in increased fuel prices. It is quite an impact on all sectors mainly engaged in the business world, because the cost of increasing production without increasing the purchasing power offset market. One effort that can be done is the use of alternative fuels economical. The question is bioethanol fuel, methanol and ethanol that requires an appropriate stove design for the fuel. To determine the level of fuel efficiency is needed stove heaters called "HD". The method used to determine the level of efficiency in the use of methanol and ethanol fuel is a method of boiling water. Measurements carried out on several parameters, namely: the volume of water in a saucepan, water temperature before it is heated, the use of heavy fuel, fuel density, temperature difference, the total energy absorbed, the amount of energy absorbed, the minimum energy required, and the amount of water boiled. Based on mathematical analysis, concluded that the use of fuel ethanol has a boiling speeds higher than methanol. The use of methanol fuel content of $85 \%$ is more economical because of savings significantly which is Rp 544,984,00 for broiler farms per 1000 larvae in one period of 40 days.
\end{abstract}

Keywords: HD stoves, ethanol, methanol, mathematical-economic analysis

\section{PENDAHULUAN}

Penggunaan bahan bakar yang efisien sangat diperlukan agar biaya yang dikeluarkan oleh masyarakat pengguna bahan bakar bisa seminimal mungkin. Para pelaku usaha yang menggunakan alat pemanas sangat berkepentingan dengan bahan bakar yang efisien ini. Beberapa industri rumah tangga, seperti produksi kerupuk dan jajanan, dan peternakan ayam potong juga memerlukan bahan bakar yang efisien. Sejauh ini, masyarakat menggunakan minyak tanah atau elpiji sebagai bahan bakarnya. Peningkatan harga minyak tanah yang mencapai Rp. 7.500,- per liter membuat masyarakat beralih ke bahan bakar elpiji bersubsidi. Namun, dengan adanya peraturan baru pembatasan subsidi untuk elpiji, maka perlu dipikirkan alternatif penggunakan bahan bakar lain yang lebih efisien dan ekonomis. Sehingga penggunaan bahan bakar selain minyak tanah dan elpiji perlu dipertimbangkan lagi.

Bahan bakar merupakan materi yang bisa diubah menjadi energi. Bahan bakar dapat dibedakan menjadi tiga jenis yaitu, bahan bakar padat, bahan bakar cair, dan bahan bakar gas. Penggunaan bahan bakar yang semakin meningkat membuat kelangkaan yang tidak pernah terduga oleh masyarakat. Pada penelitian ini, lebih dikhususkan pada penggunaan bahan bakar cair yaitu etanol dan metanol. Etanol adalah alkohol gandum, atau formula tanaman massa yang berasal dari gula alami yang ditemukan dalam massa bio, 
atau tumbuh-tumbuhan seperti jagung, gandum, barley, kentang dan tebu. Kandungan-kandungan tersebut kemudian diproses untuk membuat suatu bentuk energi terbarukan aditif bahan bakar atau bahan bakar yang baik biaya yang efektif dan baik. Sedangkan metanol merupakan cairan polar yang dapat bercampur dengan air, alkohol-alkohol lain, ester, keton, eter, dan sebagian besar pelarut organik. Metanol sedikit larut dalam lemak dan minyak. Secara fisika metanol mempunyai afinitas khusus terhadap karbon dioksida dan hidrogen sulfida. Titik didih metanol berada pada $64,7^{\circ} \mathrm{C}$ dengan panas pembentukan (cairan) $-239,03 \mathrm{~kJ} / \mathrm{mol}$ pada suhu $25^{\circ} \mathrm{C}$ (Anozie dan Bakare, 2004).

Bahan bakar metanol dan etanol tidak bisa secara langsung diterapkan pada kompor biasa. Berdasarkan jurnal penelitian terdahulu oleh Anindita Laksmi, dkk. (2010) dari ITS jurusan Teknik Industri yang berjudul Perancangan Ulang Kompor Bioetanol Dengan Menggunakan Pendekatan Metode Quality Function Deployment (QFD) dan Teoriya Resheniya Izobretatelskikh Zadatch (TRIZ), penulis mewujudkan rancangan kompor yang mampu digunakan oleh berbagai jenis bahan bakar. Kompor dimaksud bisa digunakan pada bahan bakar bioetanol, metanol, ataupun spiritus. Dari hasil rancang bangun kompor ini penulis akan meneliti tingkat efisiensi bahan bakar etanol dan metanol dengan kadar yang berbeda. Metode yang digunakan untuk menguji kompor ini adalah dengan meode air mendidih. Berdasarkan latar belakang di atas, tujuan penelitian ini adalah mengetahui nilai ekonomis penggunaan bahan bakar etanol dan metanol dalam kompor "HD", khususnya pada pemanas kandang ayam

\section{METODE}

Metode yang digunakan dalam penelitian ini akan disajikan pada Gambar 1 berikut. Dari gambar 3 dapat dilihat bahwa penelitian dilakukan dengan langkah yang diawali dengan perencanaan penelitian. Selanjutnya dimulai dengan mempersipakan alatalat untuk penelitian. Bahan yang digunakan dalam penelitian ini adalah metanol dengan beberapa variasi kadar, etanol dengan beberapa variasi kadar, air sebagai bahan yang didihkan. Peralatan yang digunakan: kompor HD, panci untuk tempat memasak air, thermometer, alkoholmeter, stopwatch, tabung ukur, dan timbangan untuk mengukur penggunaan bahan.

Kompor yang digunakan adalah kompor tanpa sumbu dengan bahan bakar cair terutama didesain untuk penggunaan bahan bakar etanol ataupun metanol. Bahan yang digunakan untuk ruang bakar kompor adalah aluminium sebagai dasar dan kaleng bekas cat sebagai tabung ruang bakar sebagai

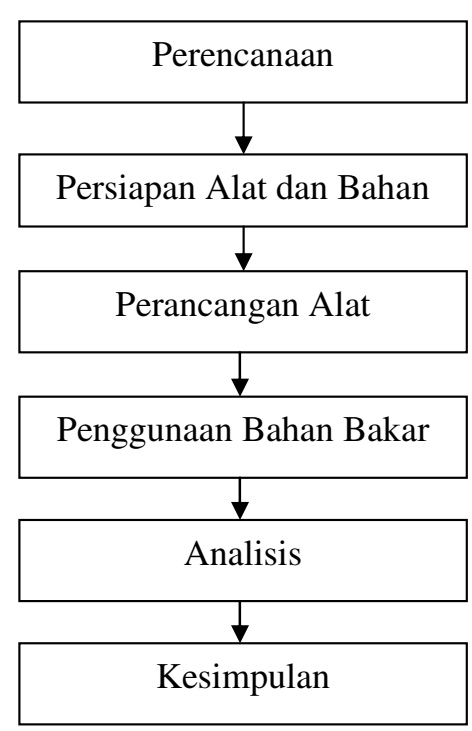

Gambar 1. Diagram Alir Penelitian

penghasil gas hasil pemanasan bahan bakar. Tabung ruang bakar atau burner memiliki lubang udara berjumlah empat buah disekeliling tabung dengan diameter 1,5 cm dan jarak antara lubang adalah 6,7 $\mathrm{cm}$. Lubang udara ini sebagai tempat asupan oksigen yang masuk ruang bakar untuk menyalakan api dengan suplai oksigen yang terbatas hanya untuk menguapkan gas bahan bakar. Tinggi tabung burner $10 \mathrm{~cm}$ dengan diameter $8,5 \mathrm{~cm}$. Bagian atas tabung memiliki lubang-lubang untuk keluarnya gas yang kemudian ditutup oleh head kompor. Di head kompor inilah api dinyalakan sebagai hasil oksidasi gas hasil pemanasan bahan bakar dengan oksigen di head kompor.

Kompor HD ini dirancang dengan sistem pembakaran gas bahan bakar hasil pemanasan bahan bakarnya. Tabung bahan bakar terpisah dengan kompor kemudian dihubungkan dengan menggunakan selang. Tabung bahan bakar tersebut dari tabung plastik transparan dengan skala pengukuran. Dengan cara ini akan lebih mudah untuk dilakukan pengukuran penggunaan bahan bakarnya. Penelitian dilakukan untuk mengetahui efisiensi bahan bakar metanol dan etanol dengan beberapa kadar metanol dan etanol dengan cara mencampurnya dengan air. Metode yang digunakan adalah metode air mendidih.

Kompor dinyalakan dengan nyala api standar untuk memasak air dalam panci terbuka untuk semua variabel bahan bakar. Target yang ingin dicapai adalah mendidihkan air dalam panci dengan jumlah air tetap untuk masing-masing bahan bakar. Panci diletakkan di atas kompor pada saat dicapai nyala api standart stabil. Termometer diletakkan di dalam air dengan posisi di tengah panci dengan 


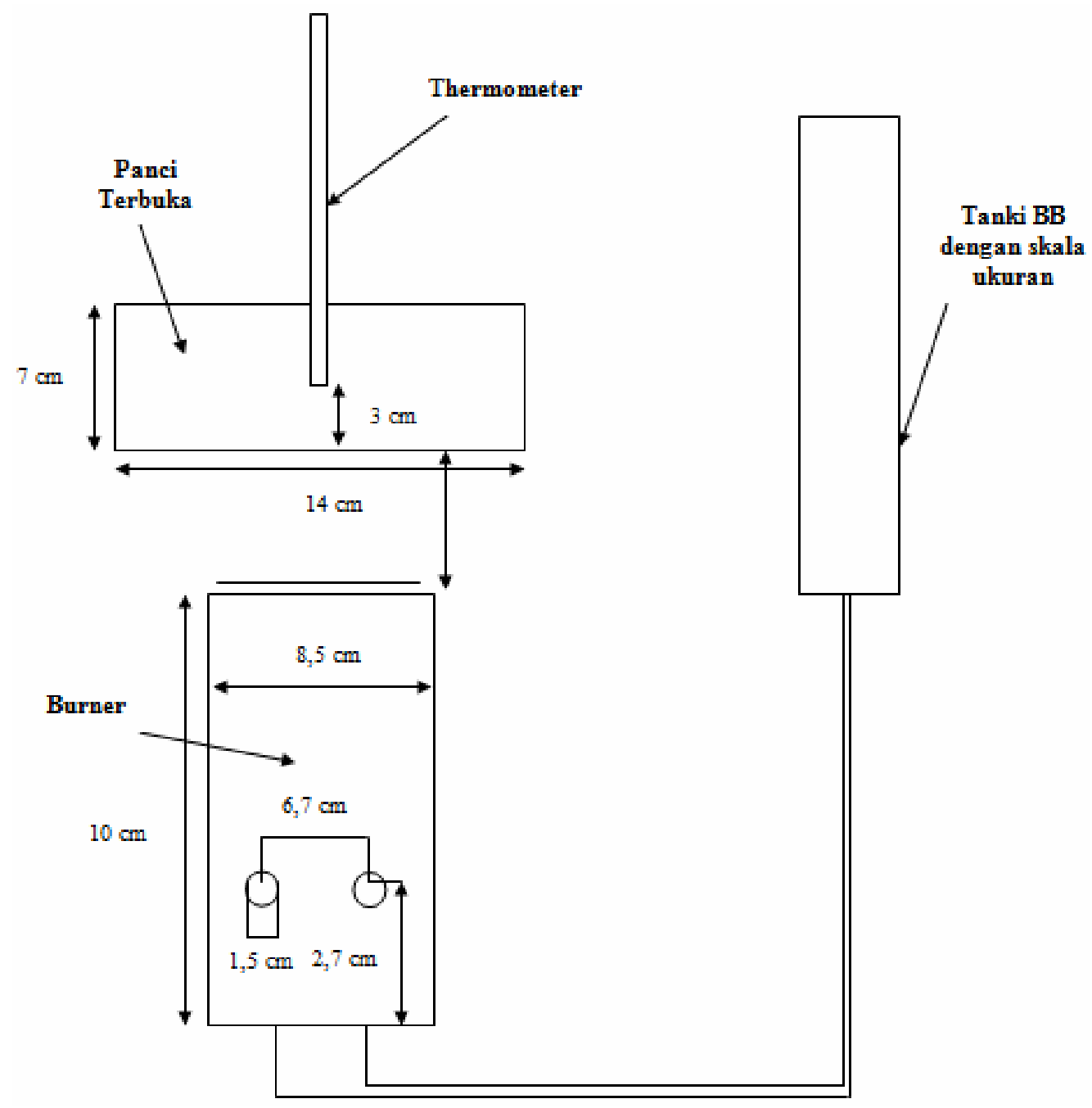

Gambar 2. Rancangan Kompor "HD"

ujung bawah thermometer berjarak $3 \mathrm{~cm}$ dari dasar panci. Jarak panci dengan head kompor adalah $3,5 \mathrm{~cm}$. Pengukuran dimulai pada saat panci diletakkan di atas kompor.

Sebelum dimulai pengukuran, ditentukan terlebih dahulu titik didih lokal dari air yang akan digunakan dalam penelitan. Titik didih lokal dari air adalah titik suhu air dimana suhu tidak tidak lagi bisa naik seberapa banyakpun panas yang diberikan pada air tersebut. Suhu pendidihan lokal ini dipengaruhi oleh beberapa faktor antara lain ketinggian lokasi, akurasi dari thermometer, dan kondisi cuaca. Sehingga titik didih lokal air tidak bisa diasumsikan $100^{\circ} \mathrm{C}$. Metode penentuan titik didih lokal air dengan mendidihkan air dalam panci yang telah dipasang thermometer seperti di atas dengan daya kompor yang tinggi. Pengamatan dilakukan selama 5 menit dan dicatat suhu thermometer terendah dan tertinggi selama periode pengamatan pada saat air mendidih penuh. Kemudian suhu ninimum dan maksimum tersebut dirata-rata sehingga didapat suhu titik didih lokal dari air tersebut.

Untuk masing-masing bahan bakar yang digunakan, bahan bakar sejumlah tertentu dimasukkan ke dalam kompor untuk dinyalakan sampai api menyala standart. Setelah tercapai nyala api standart panci dengan thermometer di dalamnya diletakkan di atas kompor pada saat itu pada tabung bahan bakar ditandai dengan spidol boardmaker untuk mengetahui penggunaan bahan bakarnya. Pada saat itu juga penggukuran waktu menggunakan stopwatch dimulai. Pada saat suhu titik didih lokal air tercapai stopwatch dimatikan dan penggunaan bahan bakar pada tabung bahan bakar dicatat penggunaan bahan bakarnya.

Serangkaian pengukuran dan analisis matematis yang dilakukan dalam penelitian ini adalah sebagai berikut. Tahap pertama, mengukur: volume air dalam panci (ml), dan suhu air sebelum dipanaskan. Tahap kedua menimbang berat bahan 
bakar (BB) yangdigunakan dan berat jenis masingmasing bahan bakar dengan cara menimbangnya secara langsung dan menghitung total energi yang diserap oleh air untuk mendidih (Kalori) (Robinson, 2006). Kalor untuk air secara spesifik adalah $1 \mathrm{kalori} / \mathrm{g}^{\circ} \mathrm{C}$. Sedangkan besarnya energi yang diserap $E=m . c . \Delta T$. Jadi total energi yang diserap $\operatorname{air}\left(E_{A I R}\right)=$ Volume Air $(m l.) \times \Delta T \times 1 \frac{\text { Kalori }}{m l} \cdot{ }^{\circ} \mathrm{C}$.

Tahap ketiga dari proses pengukuran dan analisis ini menghitung jumlah energi yang diserap oleh air per gram bahan bakar dengan rumus.

$\begin{aligned} & \text { Kalori yang diserap } \\ & \text { per gram BB }\end{aligned}=\frac{\text { Total energi yang diserap air }}{\text { Berat BB yang digunakan }}$

Tahap kelima menghitung energi minimum yang diperlukan untuk mendidihkan 1 liter air dari suhu awal di dalam penelitian. Suhu awal diukur dengan mengukur suhu air sebelum dipanaskan, sedangkan suhu akhir adalah suhu titik didih lokal. Gunakan rumus energi di atas $\left(E_{i L}=m_{i L} . c . \Delta T\right)$. Tahap selanjutnya menghitung jumlah air yang didihkan oleh 100 gram bahan bakar.

Jumlah air yang didihkan oleh 100 g BB =

Kalori yang diserap per g BB

$$
\mathrm{E}_{\mathrm{iL}}
$$

Tiap jenis bahan bakar diambil $10 \mathrm{ml}$ kemudian ditimbang sehingga diperoleh berat jenis tiap bahan bakar dengan satuan $\mathrm{gr} / \mathrm{ml}$ atau $\mathrm{kg} / \mathrm{L}$, menghitung perbedaan temperatur $\left({ }^{\circ} \mathrm{C}\right)$ antara suhu maksimal air dan suhu awal air sebelum dimasak. Perhitungan perbedaan temperaturnya adalah.

$\Delta T=T \max -T \min$

\section{HASIL DAN PEMBAHASAN}

Hasil penelitian dan analisis matematisnya tersaji dalam tabel-tabel, gambar-gambar dan uraian berikut ini.

Tabel 1. Data Hasil Pengukuran Penelitian terhadap Berbagai Bahan Bakar dan Beberapa Kadar

\begin{tabular}{lcccc}
\hline Bahan Bakar & $\begin{array}{c}\text { Massa } \\
\text { Jenis } \\
(\mathbf{g r} / \mathbf{m l})\end{array}$ & $\begin{array}{c}\text { Vol Air } \\
(\mathbf{m l})\end{array}$ & $\begin{array}{c}\text { TAWAL } \\
\left({ }^{\circ} \mathbf{C}\right)\end{array}$ & $\begin{array}{c}\text { TAKHIR } \\
\left({ }^{\circ} \mathbf{C}\right)\end{array}$ \\
\hline Metanol 100\% & 0,77 & 650 & 25 & 96 \\
Metanol 93\% & 0,775 & 650 & 25 & 96 \\
Metanol 85\% & 0,78 & 650 & 25 & 96 \\
Etanol 93\% & 0,82 & 650 & 25 & 96 \\
Etanol 85\% & 0,835 & 650 & 25 & 96 \\
\hline
\end{tabular}

Dari Tabel 1 di atas dapat disimpulkan bahwa metanol 100\%, metanol 93\%, metanol 85\%, etanol $93 \%$, dan etanol $85 \%$ dengan perlakukan suhu awal dan suhu akhir yang sama, maka didapatkan massa yang berbeda-beda.

Tabel 2. Data Hasil Pengukuran Penelitian terhadap Berbagai Bahan Bakar Dan Beberapa Kadar

\begin{tabular}{llllll}
\hline $\begin{array}{c}\text { Bahan } \\
\text { Bakar }\end{array}$ & $\begin{array}{c}\text { Massa } \\
\text { Jenis } \\
\text { (gr/ml) }\end{array}$ & $\begin{array}{c}\text { Waktu } \\
\text { Didih } \\
\text { (detik) }\end{array}$ & $\begin{array}{c}\text { Waktu } \\
\text { Didih } \\
\mathbf{1 ~ L ~} \\
\text { (detik)* }\end{array}$ & $\begin{array}{c}\text { Jumlah } \\
\text { BB di- } \\
\text { guna- } \\
\text { kan } \\
\text { (ml) }\end{array}$ & $\begin{array}{c}\text { Berat } \\
\text { BBdi- } \\
\text { guna- } \\
\text { kan } \\
\text { (gr) }\end{array}$ \\
\hline Metanol 100\% & 0,77 & 665 & 1023 & 47 & 36,19 \\
Metanol 93\% & 0,775 & 782 & 1203 & 48 & 37,2 \\
Metanol 85\% & 0,78 & 1077 & 1657 & 49 & 38,22 \\
Etanol 93\% & 0,82 & 610 & 938 & 45 & 36,9 \\
Etanol 85\% & 0,835 & 1001 & 1540 & 50 & 41,75 \\
\hline
\end{tabular}

* Estimasi waktu yang diperlukan untuk mendidihkan air 1 liter adalah 1,54 kali lebih lama dari waktu yang digunakan untuk mendidihkan air $650 \mathrm{ml}$.

Penentuan titik didih lokal yang dilakukan di daerah Kota Malang dalam suhu ruangan tanpa gangguan angin menunjukkan suhu $96^{\circ} \mathrm{C}$. Dari titik didih lokal ini kita bisa menentukan energi minimum yang diperlukan untuk mendidihkan air 1 liter yaitu dengan memasukkan rumus $E_{i L}=m_{i L}$.c. $\Delta T$. (Utomo, 1994)Suhu awal air sebelum dipanaskan diukur dengan thermometer menunjukkan angka $25^{\circ} \mathrm{C}$ sesuai dengan suhu ruangan. Sehingga didapat energi minimum yang diperlukan untuk mendidihkan air 1 liter adalah 71.000 kalori.

Dari hasil penelitian menggunakan metanol, api keluaran dari burner stabil berwarna biru untuk metanol kadar $100 \%$ dan $93 \%$, sedangkan untuk metanol kadar $85 \%$ api tetap stabil tetapi berwarna sedikit kemerahan. Sedangkan untuk metanol kadar $80 \%$ api berwarna kemerahan tetapi api menyala kurang stabil sehingga pada saat digunakan untuk memasak air suhu air bertahan pada suhu $91^{\circ} \mathrm{C}$ mulai menit ke-17 dan stabil tanpa ada kenaikan hingga ditunggu sampai 5 menit tidak ada kenaikan suhu bahkan kadang turun, sehingga penelitian untuk penggunaan bahan bakar metanol kadar $80 \%$ dihentikan.

Demikian juga untuk bahan bakar etanol dengan kadar 93\% menunjukkan nyala api biru yang stabil. Bahan bakar etanol kadar $85 \%$ juga menghasilkan nyala api yang stabil dengan sedikit kemerahan. Tetapi seperti bahan bakar metanol kadar $80 \%$, penggunaan bahan bakar etanol kadar $80 \%$ menunjukkan nyala api merah tidak stabil, sehingga dari hasil penelitian setelah dicapai suhu 
Tabel 3. Pengolahan Data

\begin{tabular}{lccccccc}
\hline \multicolumn{1}{c}{ Bahan Bakar } & Vol. (ml.) & $\boldsymbol{\Delta T}(\mathbf{o C})$ & $\begin{array}{c}\text { Berat BB } \\
\text { digunakan (gr.) }\end{array}$ & $\begin{array}{c}\text { E air } \\
\text { (kalori) }\end{array}$ & $\begin{array}{c}\text { Kalori } \\
\text { Diserap Per } \\
\text { Gr BB }\end{array}$ & $\begin{array}{c}\text { Jumlah Air } \\
\text { Didih (L)/100 } \\
\text { GR BB }\end{array}$ & $\begin{array}{c}\text { Biaya } \\
\text { mendidihkan } \\
\text { 1 L. AIR (Rp) }\end{array}$ \\
\hline Metanol 100\% & 650 & 71 & 36,19 & 46150 & 1275,21 & 1,80 & 434 \\
Metanol 93\% & 650 & 71 & 37,2 & 46150 & 1240,59 & 1,75 & 414 \\
Metanol 85\% & 650 & 71 & 38,22 & 46150 & 1207,48 & 1,70 & 400 \\
Etanol 93\% & 650 & 71 & 36,9 & 46150 & 1250,68 & 1,76 & 554 \\
Etanol 85\% & 650 & 71 & 41,75 & 46150 & 1105,39 & 1,56 & 554 \\
\hline
\end{tabular}

$94^{\circ} \mathrm{C}$ pada menit ke-17 tidak ada kenaikan suhu yang signifikan hingga kita tunggu sampai 5 menit, sehingga dihentikan penelitian penggunaan bahan bakar etanol kadar $80 \%$.

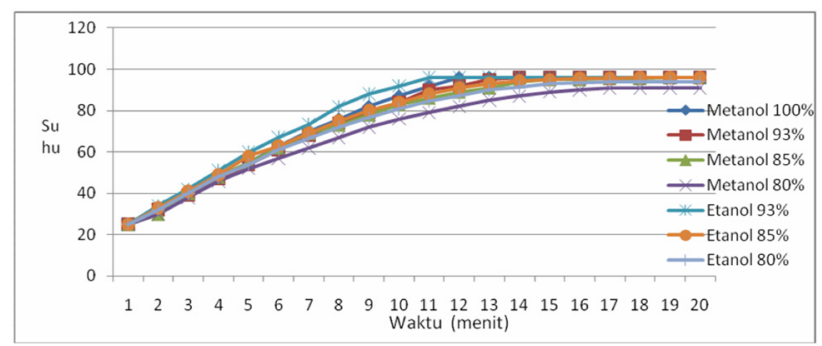

Gambar 3. Grafik Kecepatan Pendidihan Air 650 ml

Data menunjukkan kecepatan pendidihan air menggunakan bahan bakar etanol 93\% menempati urutan pertama dengan waktu 10 menit 10 detik, urutan kedua ditempati oleh bahan bakar metanol 100\% dengan waktu pendidihan 11 menit 5 detik, hal ini dipahami karena nilai kalor dari etanol 93\% masih lebih tinggi dari metanol $100 \%$. Urutan ketiga metanol kadar 93\%, disusul bahan bakar etanol 85\% kemudian terakhir metanol 85\%. Kecepatan dan efisiensi pendidihan ini juga sangat bergantung dari desain kompor yang digunakan. Penggunaan bahan kompor dengan sifat konduktor lebih baik akan dapat mempercepat proses penguapan bahan bakar yang akan dioksidasi di burner. Selain itu rancangan lubang untuk asupan udara untuk di ruang bakar juga berpengaruh dalam kesempurnaan proses oksidasi di ruang bakar untuk pemanasan bahan bakar menjadi gas yang kemudian dioksidasi lagi di head kompor.

Dari Tabel 3, dapat terlihat bahwa metanol 100\%, metanol 93\%, metanol 85\%, etanol 93\%, dan etanol $85 \%$ memiliki kalori penyerapan per gr yang berbeda. Akibatnya, biaya mendidihkan 1 liter airnya juga berbeda-beda. Untuk mengkonversi harga dalam per kg bahan bakar dengan cara:

$$
\text { Harga BB per kg }=\frac{1}{\text { massa jenis } \mathrm{BB}} \times \text { harga per liter }
$$

Tabel 4. Harga untuk Masing-masing Bahan Bakar

\begin{tabular}{lcc}
\hline \multicolumn{1}{c}{ Bahan bakar } & $\begin{array}{c}\text { Harga per liter } \\
\text { (Rp) }\end{array}$ & Harga per kg (Rp) \\
\hline Metanol 100\% & 6.000 & 7.792 \\
Metanol 93\% & 5.600 & 7.226 \\
Metanol 85\% & 5.300 & 6.795 \\
Etanol 93\% & 8.000 & 9.756 \\
Etanol 85\% & 7.200 & 8.623 \\
\hline
\end{tabular}

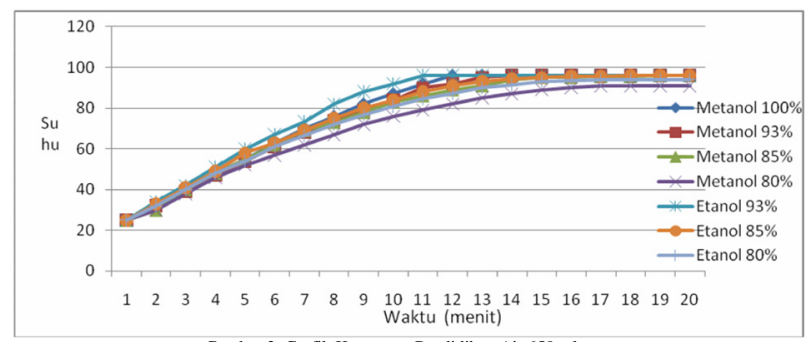

Gambar 4. Grafik antara Biaya dengan Total Waktu Penggunaan Bahan Bakar untuk Mendidihkan Air 1 Liter

Dari Gambar 4 terlihat bahwa penggunaan bahan bakar metanol masih memiliki nilai ekonomi yang tinggi dibandingkan dengan penggunaan bahan bakar etanol. Meskipun nilai kalor etanol lebih tinggi dibandingkan metanol, tetapi harga etanol yang lebih mahal belum bisa mengimbangi nilai ekonomis dari penggunaan bahan bakar metanol. Dengan penggunaan metanol 100\% dibandingkan penggunaan etanol 93\% memiliki selisih waktu pendidihan 1 liter air hanya terpaut 1 menit 25 detik. Waktu yang tidak terlaku signifikan jika digunakan untuk memasak, tetapi memiliki selisih biaya Rp. 120,- per liter air yang dididihkan.

Penggunaan bahan bahan bakar yang paling ekonomis ditunjukkan oleh pengunaan bahan bakar metanol 85\%. Dengan penggunaan bahan bakar metanol $85 \%$ sangat cocok untuk penggunaan/ aplikasi dalam usaha budidaya ayam potong, dimana diperlukan kompor untuk menghangatkan suhu sekitar dengan nyala api yang stabil dan hemat biaya. 
Tabel 5. Perbandingan Penggunaan BB Seluruh Jenis BB Hasil Penelitian dan Penggunaan Kompor BB Elpiji dalam Pemanas Kandang pada Usaha Ayam Potong

\begin{tabular}{llcl}
\hline Jenis bahan bakar & Harga & $\begin{array}{c}\text { Lama Nyala } \\
\text { (Jam) }\end{array}$ & Biaya/jam \\
\hline Elpiji 3 KG & Rp 13.000 & 8 & Rp 1.625 \\
1 liter metanol 100\% & Rp 6.000 & 3,93 & Rp 1.527 \\
1 liter metanol 93\% & Rp 5.600 & 4,53 & Rp 1.237 \\
1 liter metanol 85\% & Rp 5.300 & 6,11 & Rp 868 \\
1 liter etanol 93\% & Rp 8.000 & 3,77 & Rp 2.125 \\
1 liter etanol 85\% & Rp 7.200 & 5,56 & Rp 1.295 \\
\hline
\end{tabular}

Dari data diketahui bahwa dengan menggunakan metanol 85\%, nyala api selama 1.077 detik menghabiskan $50 \mathrm{ml}$. bahan bakar. Artinya dengan penggunaan 1 liter metanol $85 \%$ kompor bisa digunakan menyalakan api dengan stabil selama 21.980 detik atau 6 jam 6 menit. Berarti biaya pemanasan per kompor per jamnya adalah Rp 868,-

Hal ini berarti jika selama ini penggunaan kompor elpiji di lingkungan usaha peternakan ayam potong menghabiskan satu tabung elpiji subsidi kemasan $3 \mathrm{~kg}$ selama 8 jam penyalaan untuk satu kompor. Dengan asumsi harga elpiji subsidi $3 \mathrm{~kg}$ adalah Rp. 13.000,- maka biaya pemanasan per kompor per jamnya adalah Rp. 1.625,- Dengan demikian penghematan yang bisa diperoleh jika menggunakan bahan bakar metanol $85 \%$ adalah Rp. 757,- per kompor per jamnya. Suatu penghematan yang besar untuk usaha ayam potong.

Tabel 6. Perbandingan Kompor HD dengan Elpiji Untuk Penggunaan Pemanas Kandang

\begin{tabular}{|c|c|c|c|c|}
\hline Kompor & $\begin{array}{c}\text { Jenis bahan } \\
\text { bakar }\end{array}$ & Harga & $\begin{array}{l}\text { Lama } \\
\text { nyala } \\
\text { (jam) }\end{array}$ & $\begin{array}{c}\text { Biaya/ } \\
\text { jam }\end{array}$ \\
\hline $\begin{array}{l}\text { Kompor } \\
\text { Elpiji }\end{array}$ & Elpiji $3 \mathrm{~kg}$ & Rp 13.000 & 8 & Rp 1.625 \\
\hline Kompor HD & $\begin{array}{l}1 \mathrm{~L} . \text { metanol } \\
85 \%\end{array}$ & Rp 5.300 & 6,11 & Rp 868 \\
\hline
\end{tabular}
tiap titik kompor

Satu periode usaha peternakan ayam potong memerlukan pemanasan ruangan selama 15 hari pertama terus-menerus selama 24 jam per hari. Satu titik kompor memanasi suhu ruangan di sekitar ayam untuk 500 ekor ayam.

Tabel 7. Penghematan Per 1000 Ekor Ayam (2 Kompor)

\begin{tabular}{ccccc}
\hline $\begin{array}{c}\text { Jumlah } \\
\text { Kompor }\end{array}$ & $\begin{array}{c}\text { Per Hari } \\
\text { (Jam) }\end{array}$ & $\begin{array}{c}\text { Per } \\
\text { periode } \\
\text { (hari) }\end{array}$ & $\begin{array}{c}\text { Penghematan } \\
\text { Per Jam }\end{array}$ & $\begin{array}{c}\text { Total } \\
\text { Peng- } \\
\text { hematan }\end{array}$ \\
\hline 2 & 24 & 15 & Rp 757 & Rp 544.984 \\
\hline
\end{tabular}

Dengan penggunaan kompor dengan bahan bakar metanol kadar 85\% diperoleh penghematan untuk kapasitas usaha ayam potong per 1000 ekor adalah Rp. 544.984,-- per periode usaha kurang lebih 40 hari. Suatu penghematan yang tidak sedikit untuk upaya efisiensi di bidang sumber energi bahan bakar kompor pemanas.

\section{SIMPULAN}

Bahan bakar etanol bisa digunakan pada kompor HD hingga kadar etanol 85\% degan nyala api stabil berwarna biru sedikit kemerahan. Demikian juga, pada metanol kadar $85 \%$. Nyala apinya stabil berwarna biru sedikit kemerahan. Dari hasil analisis matematis dapat disimpulkan bahwa penggunaan bahan bakar etanol memiliki kecepatan pendidihan paling tinggi karena etanol memiliki nilai kalor yang paling tinggi. Walaupun waktu pendidihan metanol relatif lebih lama dibandingkan etanol, namun penggunaan bahan bakar metanol masih lebih ekonomis. Secara ekonomis, pemanas kandang ayam (pada usaha peternakan ayam potong) direkomendasikan untuk menggunakan bahan bakar metanol kadar $85 \%$ karena dari hasil penelitian menunjukkan penghematan yang sangat signfikan, yaitu Rp 544.984,- untuk peternakan ayam potong per 1000 ekor dalam satu periode usaha 40 hari.

\section{DAFTAR PUSTAKA}

Anozie, A.N and Bakare, A.R., 2004. "Evaluation of Cooking Energy Cost, Efficiency, Impact on Air Pollution and Policy in Nigeria."

Hariyanto, W.W. dkk., 2007. "Ethanol Electro-Oxidation on ptceo2/C Catalist in Direct Ethanol Fuel Cell "Journal of Chemical and Natural Resources Engineering, 2: 47-61 FKKKSA, Universiti Teknologi Malaysia.

Laksmi, A., dkk., 2010. Perancangan Ulang Kompor Bioetanol dengan Menggunakan Pendekatan Metode Quality Function Deployment (Qfd) dan Teoriya Resheniya Izobretatelskikh Zadatch (Triz). http:// digilib.its.ac.id/public/ITS-Undergraduate-12645Paper.pdf

Pusat Informasi Energi, 2003. Statistik Ekonomi Energi Indonesia 2002. Jakarta: Departemen Energi dan Sumber Daya Mineral.

Rajvansi, Anil K, dkk., 2007. Low-concentration ethanol stove for rural areas in India. Nimbkar Agricultural Research Institute (NARI).

Robinson, J., 2006. Bio-Ethanol as a Household Cooking Fuel: A Mini Pilot Study of the SuperBlu Stove in Peri-Urban Malawi. Loughborough University.

Utomo, D.P. dkk., 1994. Matematika 2 untuk Teknik. Universitas Muhammadiyah Malang. 